\title{
TAX CHALLENGES IN THE TECHNOLOGICAL AND DIGITAL CONTEXTS
}

\author{
Glória TEIXEIRA \\ Faculty of Law, University of Porto \\ gteixeira@direito.up.pt \\ Marlene Teixeira de CARVALHO \\ Bank of Portugal \\ marttcarvalho@gmail.com
}

\begin{abstract}
Society has undergone very significant technological and digital changes. The significance of e-commerce is increasing in corporate life and influences the growth of the economy in the Member States and across Europe. The inherent advantages of this reality are various but the challenges are even more and more pressing.

Delimiting our theme to the tax challenges, we refer to the difficulties existing in the national tax systems, with an inappropriate social taxation system not fitting to the current reality, with the necessity of the enforcement of VAT to the new digital services and alteration of the regulatory framework on transfer pricing, a more assertive fight against abusive tax planning, tax competition, tax evasion and double taxation (or lack thereof).

It should also be referred to problems related to consumer protection, trust and security in digital services and the processing of personal data, lack of coordination between the public administration and the need for innovation and investment to consolidate the digital single market.

The Member States and the European Union, together with the OECD, should play an active role in regulating these matters. Updating laws and policies to solve the challenges of the digital age is the only way to cope with this new reality and to ensure the economic development of the European Union, alongside consumer confidence, so that consumers can carry out balanced and safe transactions without fear.
\end{abstract}

Keywords: E-commerce; tax challenges; digital single market;

\section{Resumo}

A sociedade tem vindo a sofrer alterações muito significativas em termos tecnológicos e digitais. O comércio eletrónico assume cada vez mais importância na vida empresarial das sociedades e influencia o crescimento da economia dos Estados-Membros e de toda a Europa. Os desafios a solucionar são cada vez mais prementes.

Delimitando a nossa temática aos desafios fiscais, refiram-se as dificuldades existentes nos sistemas fiscais nacionais, com um regime de tributação das sociedades desadequado à realidade atual, com a necessidade da aplicação do IVA aos novos serviços digitais e alteração do quadro regulamentar em matéria de preços de transferência, um combate mais assertivo ao planeamento fiscal abusivo, à concorrência fiscal, à elisão fiscal e à dupla tributação (ou falta dela).

Refiram-se ainda os problemas na defesa do consumidor, a confiança e segurança nos serviços digitais e no tratamento de dados pessoais, a falta de coordenação entre a administração pública e a necessidade de inovação e investimento para sedimentar o mercado único digital.

Os Estados-Membros e a União Europeia, a par da OCDE, devem assumir um papel ativo na regulamentação destas matérias. A atualização das leis e das políticas para solucionar os desafios da era digital são a única forma de conviver com esta nova realidade e garantir o desenvolvimento económico da União Europeia, a par da confiança dos consumidores, para que estes possam efetuar, sem medo, transações comerciais equilibradas e seguras.

Palavras chave: comércio eletrónico; desafios fiscais; mercado único digital; 


\section{Introduction}

The contemporary globalized world is increasingly characterized by technological advances, fast media, e-commerce and digital economy. As a result of this new and auspicious digital era, which brings along numerous challenges, Member States are facing legal orders that are incapable of providing answers to these new realities, and in some areas they have become obsolete. This phenomenon should not be identified as a problem, but only as a necessary and enriching legal and normative evolution, which all the Member States will have to know and apply.

By mastering the challenges in the technological and digital context, it will be easier to solve the impacts, not only for each Member State but, essentially, for the whole European Union, as a digital single market. The aim of this article is to identify the challenges that exist in the European Union, in particular the tax challenges - even without intending to exhaust all of them - and to point out possible solutions to them. The way forward for this work will be facilitated by delineating two main specific objectives: 1) describe the challenges identified by the European Union over the last few years and 2) identify the legislative changes and proposals already presented and outline feasible solutions for the future. Each of these specific objectives will correspond to a chapter.

The analysis will be based upon the concept of e-commerce, its inherent advantages and disadvantages with repercussions on the challenges of the digital age, such as the problems of consumer protection, trust and security in digital services and the processing of personal data, lack of coordination between the public administration, the need for innovation and investment to seduce the digital single market. In terms of taxation, reference should be made to the existing difficulties in European tax legislation namely, a system of income taxation that is inappropriate to the current situation, the need to apply VAT to new digital services and to change the regulatory framework for transfer pricing, a more assertive fight against abusive tax planning, tax competition, tax avoidance and double taxation (or lack thereof).

The monitoring of these matters requires a sound knowledge of European and international legislation, first and foremost the OECD Recommendations and the European Commission's Directives and Communications.

The transformation of the digital economy that we know today as a result of digitization should stimulate the Member States and the European Union to seize the opportunities arising from the digital age. The establishment of a digital single market will only be possible if it is based on tax systems that are coherent and adapted to the new digital reality, respecting tax fairness and transparency, and complemented by the updating of the relevant European legislation.

\section{The Challenges}

We all know that new technologies are part of our day-to-day life. With them, all the daily life tasks have become easier and the distance in most cases is no longer a problem. The expansion of information technology, technological development, the emergence of the Internet and all that it provides have challenged society, common habits and the national legal systems. 
E-commerce is, from the outset, one of the great challenges of the digital era. With its origin in EDI (Electronic Data Interchange) technology, e-commerce should be understood as consisting of all forms of business transactions involving both organizations and individuals and which are based on electronic data processing and transmission, including text, sound and image ${ }^{1}$.

Its advantages are known, such as the ease of finding jobs, goods and services, stimulating economic growth and investing in innovation. It also strengthens the competitiveness of European industry, making communication easier and making it more flexible, at a lower cost. Accordingly, European citizens and operators shall benefit from such advantages and it is necessary that Community legislation and the characteristics of the Community legal order are adapted to that effect. Directive 2000/31/EC of the European Parliament and of the Council was one of the first ways for the European Union to ensure a high level of integration of Community legislation "in order to establish a real area without internal borders for Information society services." However, we are aware of the emergence of a set of obstacles, bottlenecks and legal obstacles to the proper functioning of the internal market ${ }^{3}$, which are a direct result of e-commerce, globalization and technological evolution.

In fact, nowadays several problems can be identified such as the deficient coordination between public authorities, where contact is fragmented and incomplete; a lack of consolidation of the global financial system; a lack of interoperability, which implies that businesses and citizens are overburdened by different legal systems when they carry out electronic transactions; prevention of unfair discrimination of consumers and businesses is lacking and confidence or security in digital services and the processing of personal data could be improved ${ }^{4}$. In addition, as digital markets are being segmented, more investment in networks is needed, in combination with more research and innovation ${ }^{5}$ efforts, and also a greater improvement of electronic and digital skills. There are great potential in the emergence of these new services ${ }^{6}$, but the European Union is not fully benefiting from this new reality.

The tax framework of the European Union can be pointed out as one of the main challenges to be solved, which we intend to address more specifically in this article. It will be easy to understand that

\footnotetext{
${ }^{1}$ See, National Initiative for Electronic Commerce, Resolution of the Council of Ministers no. 94/99, Diário da República No. 198, 1. Series B, August 25, 1999 - Recommendation of the Council Guidelines for the protection of consumers in the context of E-commerce, available in https://read.oecdilibrary.org/governance/recomendacao-do-conselho-relativa-as-linhas-directrizes-que-regem-a-proteccao-dosconsumidores-no-contexto-do-comercio-electronico 9789264065802 -pt\#page5.

2 Directive 2000/31/EC of the European Parliament and of the Council of 8 June 2000, on certain legal aspects of information society services, in particular E-commerce, in the internal market («(Directive on E-commerce») Memorandum 3 of the Directive. In Portugal it was transposed through Decree-Law no. 7/2004 of January 7.

3 "According to Article 14 (2) of the Treaty, the internal market comprises an area without internal frontiers in which the free movement of goods and services and freedom of establishment are ensured." See: Directive 2000/31/EC of the European Parliament and of the Council of 8 June 2000 - Memorandum 1.

${ }^{4}$ This is due, for example, to the lack of knowledge of their rights and obligations.

For further developments see, Organization for Economic Co-operation and Development - Recommendation on the guidelines for the protection of consumers in the context of E-commerce.

${ }^{5}$ See Communication from the Commission to the European Parliament, the European Council, the Council, the European Economic and Social Committee and the Committee of the Regions - "A new European Agenda for Research and Innovation - Opportunity for Europe to chart its future" - COM (2018) 306 final - Brussels, 15.5.2018.

${ }^{6}$ For example, in the fields of content and media, health and smart energy meters. See also the Communication from the Commission to the European Parliament, the European Council, the Council, the European Economic and Social Committee and the Committee of the Regions - "Artificial Intelligence for Europe" - COM (2018) 237 final - Brussels, 25.4.2018.
} 
the changes we see today as good and desirable in structural, societal, mercantile and technological terms cause serious disruption to existing national and European legislation. The tax regimes of today's societies - both national, European and international - are out of date ${ }^{7}$ and in need of reform. They have been designed for traditional business models that are not compatible with current globalization - with new modes of value creation in the digital economy ${ }^{8}$, that require less physical presence and where user contributions and intangible assets play an important role - and with the problems we have already pointed out above. A careful, structured and systematic change is needed, the only one capable of ensuring the uniqueness and effectiveness of the whole digital single market. It should be noted that the implications go far beyond traditional models such as "economics, politics, governance, enforcement and business models, but also tax and customs administration."

We can recall that other problems related to double taxation, tax competition, and abusive tax planning ${ }^{10}$ had already been identified since the early 1990s. In order to prevent these and other tax obstacles, the European Union has legislated through the «Parent-Subsidiary Directive» and «Interest and Royalties Directive ${ }^{11}$ or has used the non-binding Code of Conduct on Business Taxation. However, technological developments, new models of value creation in the digital economy and increasingly fierce tax competition between Member States have led to the reduction of corporate tax revenues $^{12}$, despite the support in the Annual Growth Survey for 2015 which recommends that "broadening tax bases, simplification and enhanced transparency can also help increase the efficiency of the tax system and improve tax compliance as well as the fight against aggressive tax planning."13

\footnotetext{
7 "The corporate tax systems in place today were conceived to a large extent in the aftermath of World War I. At that time, multinational enterprises were mostly industrial companies, selling tangible products. Business models were largely decentralised, with production processes clearly divided between parent and subsidiary companies. This made source taxation, whereby profits are taxed where they arise, relatively simple to apply. To ensure the fair distribution of tax revenues between countries, while avoiding double taxation, transfer pricing based on the arm's length principle (ALP) was devised. The ALP ensured that the price of intra-group transactions matched comparable market prices, thereby providing a clear means of allocating profits within a multinational enterprise. To resolve cross-border disputes on corporate taxation, bilateral treaties were chosen as the preferred tool, rather than a multilateral approach." See Communication from the Commission to the European Parliament and to the Council - "A fair and efficient Corporate Tax System in the European Union: five Keys areas for action" - COM (2015) 302 final - Brussels, 17.6.2015, p. 3.

8 It is also seen that "the collaborative economy, by generating social value in the digital economy environment, may offer a new opportunity for growth and development for the countries of the European Union, as it allows untapped resources to be mobilised and gives the initiative to individual people." $p$. 1. For further developments see Opinion of the European Economic and Social Committee on Taxation of the collaborative economy analysis of possible tax policies faced with the growth of the collaborative economy (exploratory opinion requested by the Estonian presidency) (2018/C 081/09) - 2.3.2018.

9 Communication from the Commission to the European Parliament and the Council - "A fair and efficient tax system in the European Union for the digital single market" - COM (2017) 547 final - Brussels, 21.9.2017, p. 3.

10 For further developments see Communication from the Commission to the European Parliament and the Council - "Fiscal Anti-Offset Package: Next Steps for Effective Taxation and Greater Fiscal Transparency in EU" - COM (2016) 023 Final - Brussels, 28.1.2016.

${ }^{11}$ Council Directive 2003/49/EC of 3 June 2003 on a common system of taxation applicable to interest and royalty payments made between associated companies of different Member States. In Portugal, it was transposed by Law no. 55/2013 of August 08, 2013, which amended the Corporate Income Tax Code, approved by DecreeLaw no. 442-B / 88, dated December 30, November.

${ }_{12}^{12}$ For further developments in tax and business tax rates see COM (2015) 302 final.

${ }^{13}$ Communication from the Commission to the European Parliament, the Council, the European Central Bank, the European Economic and Social Committee, the Committee of the Regions and the European Investment Bank - "Annual Growth Survey 2015" - COM (2014) 902 final - Brussels, 28.11.2014, p.15.
} 
It is time to weigh the need for tax fairness (which is increasingly desired ${ }^{14}$, first and foremost by ensuring non-distortion that damages the single market), on the one hand, and the search for more attractive and competitive regimes, on the other, which further complicates the already arduous task of the European Union and the OECD/G20 ${ }^{15}$. The challenge is also to deal with the creation of national unilateral measures that are parallel to European regulations and which exacerbate the risk of fragmentation ${ }^{16}$. The inertia in solving this problem will only lead to more opportunities for tax evasion, reduced tax revenue for public budgets, a move away from equity and social justice, and increased fiscal uncertainty.

Today, 'the application of the current corporate tax rules to the digital economy has led to a misalignment between the place where the profits are taxed and the place where value is created." 17 It is questionable how to regulate when there are no physical and intermediate physical boundaries, how to identify the buyer and seller, how to qualify income obtained, how to delimit concepts as a permanent establishment?

For example ${ }^{18}$, the following criteria can be seen as one of the aims to achieve a fairer and more efficient taxation ${ }^{19}$ : "The underlying principle for corporation tax is that profits should be taxed where the value is created. ${ }^{20}{ }^{21}$ But, where to tax when value is highly fragmented or difficult to allocate $?^{22}$ What type of tax shall apply to digital transactions? $?^{23}$ These are major challenges. In addition, each Member State must ensure that it is able to properly assess the activities of the companies under its jurisdiction.

Last, but not least, the single market has to be protected and the European Union has to address all these issues externally (e.g OECD and BEPS project), "to deal with non-cooperative tax jurisdictions and to increase tax transparency ${ }^{\text {,24 }}$.

\footnotetext{
14 " All taxpayers must pay their fair share, to ensure the level playing field between businesses that is central to the success of the Single Market, and also to protect the European Social Model on which citizens depend." Communication from the Commission to the European Parliament and the Council - "Time to establish a modern, fair and efficient taxation standard for the digital economy" - COM (2018) 146 final - Brussels, 21.3.2018, p. 3.

${ }^{15}$ The OECD has examined this issue in the context of the OECD / G20 BEPS Project - OECD Report on Action 1 of the BEPS "Addressing the Tax Challenges of the Digital Economy", 2015, available in http://www.oecd.org/tax/addressing-the-tax-challenges-of-the-digital-economy-action-1-2015-final-report9789264241046-en.htm.

${ }_{17}^{16}$ Member States will accept flexibility but the existence of minimum standards is mandatory.

17 Proposal for a Council Directive laying down rules relating to the corporate taxation of a significant digital presence - COM (2018) 147 final - 2018/0072 (CNS) - Brussels, 21.3.2018, p. 1.

${ }^{18}$ For further developments regarding the tax challenges arising from the digitization of the world economy, see COM (2018) 147 final.

${ }^{19}$ The approach should pursue the following objectives: equity, competitiveness, integrity of the single market, sustainability. For further development see COM (2017) 547 final.

${ }^{20} \mathrm{COM}(2017) 547$ final, p. 7.

${ }^{21}$ As envisaged in the June 2015 Action Plan for a Fair and Effective Taxation of Societies in the EU (Action Plan for a Fair and Efficient Corporate Tax System in the EU), June 2015. Available at https://ec.europa.eu/taxation customs/business/company-tax/action-plan-corporate-taxation en. For further developments see COM (2016) 023 final.

22 " How to establish and protect taxing rights in a country where businesses can provide services digitally with little or no physical presence despite having a commercial presence." See COM (2017) 547 final, p. 7

23" How to attribute profit in new digitalised business models driven by intangible assets, data and knowledge." See COM (2017) 547 final, p. 7.

${ }^{24} \mathrm{COM}(2015) 302$ final, p. 6.
} 


\section{The Legislative Proposals}

After the financial crisis which began in 2008 , there has been a period of transformation ${ }^{25}$. In this context, in order to combat the above-mentioned and other problems, the Commission, on 3 March 2010, put forward a strategy for a smart, sustainable and inclusive growth, commonly known as "Europe 2020"26, where five quantifiable EU targets for the 2020 horizon have been presented "that will steer the process and be translated into national targets: for employment; for research and innovation; for climate change and energy; for education; and for combating poverty ${ }^{27}$. Alongside these, the Europe 2020 strategy set out three priorities: smart, sustainable and inclusive growth, which could be achieved through seven key initiatives, of which we highlight one of relevance for the case under consideration: "- "A digital agenda for Europe" to speed up the roll-out of high-speed internet and reap the benefits of a digital single market for households and firms.,28

In addition, the European Union believes that it is of the utmost importance to create a single market capable of creating a favorable climate for investment in digital networks, research and innovative companies ${ }^{29}$. This digital single market "is one in which the free movement of goods, persons, services and capital is ensured and where individuals and businesses can seamlessly access and exercise online activities under conditions of fair competition, and a high level of consumer and personal data protection, irrespective of their nationality or place of residence. ${ }^{, 30}$ From this, or hypothetically, if all the obstacles to its proper functioning (some already explained above) are tackled and the market is fully operational - incalculable benefits may come for the European Union, such as the further increase in European GDP, the expansion of the digital economy, the promotion of better and new services, etc.

\footnotetext{
${ }^{25}$ Recall the words of José Manuel Barroso: "2010 must mark a new beginning. I want Europe to emerge stronger from the economic and financial crisis. (...) The last two years have left millions unemployed. It has brought a burden of debt that will last for many years. It has brought new pressures on our social cohesion. It has also exposed some fundamental truths about the challenges that the European economy faces. And in the meantime, the global economy is moving forward. How Europe responds will determine our future." See Commission Communication Preface - "Europe 2020 - A strategy for smart, sustainable and inclusive growth" COM (2010) 2020 final - Brussels, 3.3.2010, p. 1.

${ }_{27}^{26}$ See EUROPA 2020 - Estratégia para um crescimento inteligente, sustentável e inclusivo, COM(2010) 2020.

${ }^{27} \mathrm{COM}(2010) 2020$ final, p. 4.

${ }^{28} \mathrm{COM}$ (2010) 2020 final, p. 6. "The aim is to deliver sustainable economic and social benefits from a Digital Single Market based on fast and ultra fast internet and interoperable applications, with broadband access for all by 2013, access for all to much higher internet speeds (30 Mbps or above) by 2020, and 50\% or more of European households subscribing to internet connections above 100 Mbps." See COM (2010) 2020 final, p. 14. For further developments, see Communication from the Commission to the European Parliament, the Council, the European Economic and Social Committee and the Committee of the Regions -"A Digital Agenda for Europe" - COM (2010) 245 final/2 - Brussels, 26.8.2010. It should be noted that the creation of opportunities for tax administrations, solutions to reduce administrative burdens, collaboration between tax administrations and the fight against tax avoidance are some of the many advantages inherent in the digital single market.

${ }^{29}$ See Communication from the Commission to the European Parliament, the Council, the European Economic and Social Committee and the Committee of the Regions - "Upgrading the Single Market: more opportunities for people and business" - COM (2015) 550 final - Brussels, 28.10.2015.

${ }^{30} \mathrm{COM}(2015) 192$ final, p. 3.
} 
This market is based on three pillars: 1) Better access for consumers and businesses to goods and services online across Europe; 2) Creating the right conditions for the development of digital networks and services; and 3) Optimizing the growth potential of our European Digital Economy ${ }^{31}$.

The European Union has also made use of the Digital Agenda (one of the seven initiatives of the Europe 2020 strategy), where proposals for urgent actions are formulated which may help the European Union to comply with the Europe 2020 plan such as the strengthening of the telecommunications services, access to content, simplifying cross-border and online transactions, building confidence in digital technology, standards and interoperability through coordination, among others.

The European Union, outlined its strategy as mentioned above, and since then has been legislating $^{32}$ and proposing a set of changes to the national systems in search for the necessary regulatory balance in its various areas and full operation of the digital single market ${ }^{33}$. In the tax field, the Commission Report of May $2014^{34}$ - identified as urgent to tackle the problems of erosion of the taxable base and transfer of profits ${ }^{35}$, namely in the context of the digital economy.

Meanwhile, EU member states implemented a set of norms that strengthened tax transparency ${ }^{36}$ and signed international agreements with Switzerland, Andorra, Liechtenstein, San Marino and Monaco $^{37}$. Tighter rules have been put in place to prevent EU funds being invested in tax havens ${ }^{38}$ and other measures to prevent companies from taking advantage of the asymmetries between the tax

\footnotetext{
${ }^{31}$ For further development see COM (2015) 0192 final and Annex: roadmap for the full realization of the digital single market.

32 See Regulation (EU) No 1025/2012 of the European Parliament and of the Council of 25 October 2012 on European standardization, amending Council Directives 89/686/EEC and 93/15/EEC and Directives 94/9/EC, 94/25/EC, 95/16/EC, 97/23/EC, 98/34/EC, 2004/22/EC, 2007/23/EC, 2009/23/EC and 2009/105/EC of the European Parliament and of the Council and repealing Council Decision 87/95/EEC and Decision No 1673/2006/EC of the European Parliament and of the Council. See Communication from the Commission to the European Parliament, the Council, the European Economic and Social Committee and the Committee of the Regions "European Standards for the 21st Century" - COM (2016) 358 final - Brussels, 1.6.2016; Interinstitutional Agreements between the European Parliament, the Council of the European Union and the European Commission on better law-making of 13 April 2016, and European Commission Communication from the Commission - "EU law: Better results through better application" - C/2016/8600 - (2017/C 18/02) 19.1.2017.

${ }^{33}$ For further development see Communication from the Commission to the European Parliament, the European Council, the Council, the European Economic and Social Committee and the Committee of the Regions "Completing a trusted Digital Single Market for all - The European Commission's contribution to the Informal EU Leaders' meeting on data protection and the Digital Single Market in Sofia on 16 May 2018" - COM (2018) 320 final e ANNEX - Brussels 15.5.2018.

${ }^{34}$ See Report of the European Commission Expert Group on Taxation of the Digital Economy, May 28, 2014, available at http://europa.eu/rapid/press-release IP-14-604 pt.htm.

${ }^{35}$ See Base Erosion and Profit Shifting - BEPS Project.

36 Council Directive (EU) 2015/2376; Council Directive (EU) 2016/881; Council Directive (EU) 2016/2258; Proposal for a Directive of the European Parliament and of the Council amending Directive 2013/34/EU as regards the disclosure of information on income tax by certain undertakings and branches - COM (2016) 198 final - Strasbourg, 12.4.2016; Proposal for a Council Directive amending Directive 2011/16/EU as regards automatic exchange of obligatory information in the field of taxation with regard to cross - border mechanisms to be communicated - COM (2017) 335 final - Brussels, 21.6.2017.

${ }^{37}$ ANNEX - COM (2018) 146 final.

${ }^{38}$ September 2016. ANNEX - COM (2018) 146 final.
} 
systems of the Member States and third countries ${ }^{39}$. They also implemented dispute settlement mechanisms in tax matters ${ }^{40}$ and adopted binding rules in the fight against tax avoidance ${ }^{41}$.

Within this framework, recently, in the Communication from the Commission to the European Parliament and the Council - "Time to establish a modern, fair and efficient taxation standard for the digital economy ${ }^{\wedge 2}$, the Commission specified a number of requirements in adapting the corporate tax system to the 21 st century. Accordingly, it presented a Directive proposal on company taxation with a significant digital presence ${ }^{43}$ and a proposal for a Directive on a common system of a digital services tax.

However, and notwithstanding the validity of the proposed tax Directives, it remains to be seen if member states accept these new tax frameworks.

On the other hand, in international terms, the European Union cannot disregard relations with third countries, guaranteeing an efficient, equitable and competitive market ${ }^{44}$ between EU companies and third countries. To this end, Member States have been concluding double taxation conventions, which will follow closely a Commission recommendation, thus avoiding legislative disharmony and fragmentation in national tax systems.

Finally, the European Union is committed to legislate on other issues where the challenges are also present, as we have seen above, and which can influence the smooth and efficient functioning of the digital single market ${ }^{45}$. Reference should be made namely, to the Regulation on roaming in the European Union ${ }^{46}$, the European Union's Regulation on trust services ${ }^{47}$, the adoption of a European

${ }^{39}$ October 2016. ANNEX - COM (2018) 146 final.

${ }^{40}$ Council Directive (EU) 2017/1852 of 10 October 2017 on tax dispute resolution mechanisms in the European Union.

${ }^{41}$ Council Directive 2015/2376 of 8 December 2015 amending Directive 2011/16/EU with regard to compulsory automatic exchange of information in the field of taxation; Council Directive 2016/881 of 8 December 2015 amending Directive 2011/16/EU as regards compulsory automatic exchange of information in the field of taxation; Council Regulation (EU) 2016/1164 of 12 July 2016 laying down rules against tax evasion practices directly affecting the functioning of the internal market and Council Directive 2017/952 of 29 May 2017 amending Directive 2016/1164 as regards hybrid asymmetries with third countries. In Portugal, Law No 98/2017 of 24 August implemented Council Directives (EU) 2015/2376 and (EU) 2016/881, and amended several diplomas.

${ }^{42}$ COM (2018) 146 final, p. 1.

${ }^{43}$ See, COM (2018) 147 final.

44 "New business models should support entrepreneurship while ensuring a level playing field. All levels of policymaking must ensure that the regulatory environment is simple and supportive to entrepreneurs, especially SMEs. As highlighted in the Commission's reflection paper on harnessing globalization (...)" (available at https://ec.europa.eu/commission/sites/beta-political/files/reflection-paper-globalisation en.pdf ) See COM (2018 146 final, p. 3.

${ }^{45}$ For further developments See Communication from the Commission to the European Parliament, the Council, the European Economic and Social Committee and the Committee of the Regions - "Commission Work Program 2018" - COM (2017) 650 final - Strasbourg, 24.10.2017, in particular, Annex 1.

${ }^{46}$ Regulation (EU) 2015/2120 of the European Parliament and of the Council of 25 November 2015 laying down measures concerning open internet access and amending Directive 2002/22/EC on universal service and users' rights relating to electronic communications networks and services and Regulation (EU) No 531/2012 on roaming on public mobile communications networks within the Union.

47 Regulation (EU) No 910/2014 of the European Parliament and of the Council of 23 July 2014 on electronic identification and trust services for electronic transactions in the internal market and repealing Directive 1999/93/EC. 
Parliament Resolution on E-platforms and the digital single market ${ }^{48}$ and the implementation of an EUwide online dispute resolution platform ${ }^{49}$.

Other measures are worth mentioning such as adoption of a European Cybersecurity Strategy ${ }^{50}$ with the implementation of the Network and Information Security Directive ${ }^{51}$ and the implementation of the European Security Agenda ${ }^{52}$, the approval of the General Data Protection Regulation ${ }^{53}$, the Directive on the protection of data in the field of police and judicial authorities with regard to the processing of personal data and the free movement of such data ${ }^{54}$, the adoption of a Communication on international data flows ${ }^{55}$, the proposal for the revision of the Regulation on consumer protection cooperation $^{56}$, the conclusion of a new deal for consumers ${ }^{57}$, the adoption of measures to update the

${ }^{48}$ Of 15 June 2017 - (2016/2276 (INI)) and Regulation of the European Parliament and of the Council on the creation of a digital single platform for the provision of access to information, procedures and support and resolution services for problems and amending Regulation (EU) No 1024/2012 - PE-CONS 41/18 - Brussels, 49 14.09.2018.

(2015)

192

final

and

https://ec.europa.eu/consumers/odr/main/index.cfm?event=main.home.show\&lng=EN.

${ }_{50}$ JOIN (2013) 1 final. See also the Communication "Resilience, deterrence and defense: building strong cybersecurity for the EU" - JOIN (2017) 450 - Brussels, 13.9.2017.

${ }^{51} \mathrm{COM}(2013) 48$ final. In connection with these matters, see the Opinion of the European Economic and Social Committee on the Communication from the Commission to the European Parliament, the Council, the European Economic and Social Committee and the Committee of the Regions: "Protecting businesses from misleading commercial practices and effective implementation of the rules" - Revision of Directive 2006/114/EC on misleading and comparative advertising - COM (2012) 702 final - (2013/C 271/11) - 19.9.2013.

$52 \mathrm{COM}$ (2015) 185 final and https://ec.europa.eu/home-affairs/what-we-do/policies/european-agendasecurity en. Furthermore, with the aim of meeting the objectives of the Agenda for the European Criminal Investigation Decision, Directive 2014/41/EU of the European Parliament and of the Council of 3 April 2014 on the European Investigation Order Criminal Law and the Fourth Money Laundering Directive (Directive 2015/849 of the European Parliament and of the Council of 20 May 2015 on prevention of the use of the financial system for the purposes of money laundering or terrorist financing, amending Regulation (EU) No 648/2012 of the European Parliament and of the Council, and repealing Directive 2005/60/EC of the European Parliament and of the Council and Commission Directive 2006/70/EC). In Portugal see Law No. 83/2017, of August 18 and Law No. 89/2017, of August 21. See also the European Parliament and Council Directive 2016/1148 of 6 July 2016 concerning measures for a high common level of security of network and information systems across the Union. In Portugal, see Law no. 46/2018, of August 13, 2018.

${ }^{53}$ Regulation (EU) 2016/679 of the European Parliament and of the Council of 27 April 2016 on the protection of natural persons with regard to the processing of personal data and on the free movement of such data and repealing Directive 95/46/EC and Proposal for a Regulation of the European Parliament and of the Council on the protection of individuals with regard to the processing of personal data and on the free movement of such data (General Data Protection Regulation) COM (2012) 11 final - Brussels, 25.1.2012.

${ }^{54}$ Directive 2016/680 of the European Parliament and of the Council of 27 April 2016 on the protection of persons with regard to the processing of personal data by competent authorities for the purposes of the prevention, investigation, detection or prosecution of criminal offences or the execution of criminal penalties, and on the free movement of such data, and repealing Council Framework Decision 2008/977/JHA.

${ }^{55}$ See http://europa.eu/rapid/press-release MEMO-17-15 en.htm.

${ }^{56}$ Regulation (EC) No 2006/2004 of the European Parliament and of the Council of 27 October 2004 on cooperation between national authorities responsible for the enforcement of consumer protection laws (the Regulation on consumer protection cooperation) - "that will clarify and develop the powers of enforcement authorities and improve the coordination of their market monitoring activities and alert mechanisms to detect infringements faster." See COM (2015) 192 final, p. 5. See also in these matters the Proposal for a Directive of the European Parliament and of the Council amending Council Directive 93/13/EEC of 5 April 1993, Directive 98/6/EC of the European Parliament and of the Directive 2005/29/EC of the European Parliament and of the Council and Directive 2011/83/EU of the European Parliament and of the Council as regards better enforcement and modernization of EU consumer protection rules - (COM 2018) 185 final. In Portugal, see Decree-Law no. 24/2014, of February 14 and Law no. 47/2014, of July 28. Furthermore, Directive 2006/123/EC of the European Parliament and of the Council of 12 December 2006 on services in the internal market, which regulates the purchase or contracting of services by consumers in other European Union countries or the provision of professionals in these countries. In Portugal, see Decree-Law no. 49/2010, of May 19.

${ }^{57}$ See Communication from the Commission to the European Parliament, the Council and the European Economic and Social Committee - "A New Deal for Consumers" - COM (2018) 183 final - Brussels, 11.4.2018. 
regime on misleading and comparative advertising ${ }^{58}$, the adoption of the SOLVIT Action Plan, the creation of the 'Your Europe' Portal ${ }^{59}$, of the Single Points, the Product Contact Points, and the Contact Points for Construction products and the presentation of a proposal for the creation of a Digital Single web Portal ${ }^{60}$ and the European E-Justice Portal ${ }^{61}$.

The Commission also adopted a series of measures to reinforce the Capital Markets Union $(\mathrm{CMU})^{62}$, such as the Proposal for a Directive of the European Parliament and of the Council amending Directive 2009/65/EC of the European Parliament and of the Council and Directive 2011/61/EU of the European Parliament and of the Council as regards the cross-border distribution of collective investment funds ${ }^{63}$, which is foreseen in the Commission Work Program $2018^{64}$, and should be integrated into the Capital Markets Union Action Plan for the $\mathrm{CMU}^{65}$.

\section{Conclusions}

Every day more than 360 million Europeans use the internet in their daily lives. The challenges inherent in this, as we have seen, are immense and can only be solved by creating a genuine digital single market, integrated in a more cohesive, strong and democratic European Union. E-commerce requires an equitable single market that must be interlinked with effective strategies that foster innovation and economic growth and be open to new global partners.

The proper functioning of this market will depend, first and foremost, in the areas of justice and fundamental rights, on mutual trust, to be guaranteed by the citizens' well-being and effectiveness in obtaining structural solutions in the various areas of European Union intervention, notably the creation of a modern and fair tax framework for the economy, which is conducive to growth. In fact, all these realities must be properly framed in national legal systems and, even before this application, it is mandatory to achieve some form of consistency in European and international law. Only in this way will it be possible to safeguard that the positions taken by the Member States doesn't dismember the single market and make legal implementation and adaptation to these new concepts even more difficult.

The European Union has clearly identified the great majority of the challenges arising from the digital age and has, over the last few years, come up with numerous legislative proposals and adopted

\footnotetext{
${ }^{58}$ COM (2012) 702 final (2013/C 271/11).

${ }^{59}$ See https://europa.eu/youreurope/citizens/index en.htm .

60 "The Commission considers that any established company should be able to expand its operations crossborder online and be pan-European within a month building on the interconnection of business registers and the 'Once-Only' principle." See COM (2015) 192 final, p. 17 and see further http://europa.eu/rapid/press-release IP$17-1086$ en.htm.

${ }^{61}$ https://e-justice.europa.eu/content find a company-489-en.do . For further developments see Report from the Commission - Monitoring the application of European Union law 2017 Annual Report - COM (2018) 540 final Brussels, 12.7.2018.

${ }^{62}$ Communication from the Commission to the European Parliament, the Council, the European Economic and Social Committee and the Committee of the Regions - "Action Plan on building a Capital Markets Union" COM (2015) 468 final - Brussels, 30.9.2015.

${ }^{63} \mathrm{COM}$ (2018) 92 final - Brussels 12.3.2018.

${ }^{64}$ COM (2017) 650 final.

${ }^{65}$ COM (2015) 468 final and Communication from the Commission to the European Parliament, the Council, the European Economic and Social Committee and the Committee of the Regions - "On the Mid-term Review of the Capital Markets Union Action Plan" - COM (2017) 292 final - Brussels, 8.6.2017.
} 
various strategies to solve these problems. The path is open but ultimately it will be up to the Member States to move forward and to complete the strategies presented by the European Union. The central priority of the Member States should be to achieve fair, competitive, efficient, growth-enhancing and digital-friendly standards, which must be implemented in each national system, respecting the rules, principles and objectives defined by the Union European Union.

\section{Informação:}

"Qualquer opinião expressa neste artigo pertence unicamente à autora, não representando a opinião do Banco de Portugal, a menos que expressamente se afirme que a autora está autorizada para tanto."

\section{Bibliography}

Commission Communication Preface - "Europe 2020 - A strategy for smart, sustainable and inclusive growth" - COM (2010) 2020 final - Brussels, 3.3.2010.

Communication from the Commission to the European Parliament, the Council, the European Economic and Social Committee and the Committee of the Regions -"A Digital Agenda for Europe" - COM (2010) 245 final/2 - Brussels, 26.8.2010

Opinion of the European Economic and Social Committee on the Communication from the Commission to the European Parliament, the Council, the European Economic and Social Committee and the Committee of the Regions: "Protecting businesses from misleading commercial practices and effective implementation of the rules" - Revision of Directive 2006/114/EC on misleading and comparative advertising - COM (2012) 702 final - (2013/C 271/11) - 19.9.2013.

Report of the European Commission Expert Group on Taxation of the Digital Economy, May 28, 2014. Available at http://europa.eu/rapid/press-release IP-14-604 pt.htm. [Accessed 25 October 2018]

Communication from the Commission to the European Parliament, the Council, the European Central Bank, the European Economic and Social Committee, the Committee of the Regions and the European Investment Bank - "Annual Growth Survey 2015" - COM (2014) 902 final - Brussels, 28.11.2014

Communication from the Commission to the European Parliament, the Council, the European Economic and Social Committee and the Committee of the Regions - "A Digital Single Market Strategy for Europe" - COM (2015) 192 final - Brussels, 6.5.2015.

Action Plan for a Fair and Effective Taxation of Societies in the EU (Action Plan for a Fair and Efficient Corporate Tax System in the EU), June 2015. Available at https://ec.europa.eu/taxation customs/business/company-tax/action-plan-corporatetaxation en. [Accessed 25 October 2018]

Communication from the Commission to the European Parliament and to the Council - "A fair and efficient Corporate Tax System in the European Union: five Keys areas for action" - COM (2015) 302 final - Brussels, 17.6.2015.

Communication from the Commission to the European Parliament, the Council, the European Economic and Social Committee and the Committee of the Regions - "Action Plan on building a Capital Markets Union" - COM (2015) 468 final - Brussels, 30.9.2015.

Communication from the Commission to the European Parliament, the Council, the European Economic and Social Committee and the Committee of the Regions - "Upgrading the Single Market: more opportunities for people and business" - COM (2015) 550 final - Brussels, 28.10.2015 
OECD Report on Action 1 of the BEPS «Addressing the Tax Challenges of the Digital Economy», 2015. Available at http://www.oecd.org/tax/addressing-the-tax-challenges-of-the-digitaleconomy-action-1-2015-final-report-9789264241046-en.htm. [Accessed 25 October 2018]

Communication from the Commission to the European Parliament and the Council - "Fiscal AntiOffset Package: Next Steps for Effective Taxation and Greater Fiscal Transparency in EU" COM (2016) 023 Final - Brussels, 28.1.2016.

Proposal for a Directive of the European Parliament and of the Council amending Directive 2013/34/EU as regards the disclosure of information on income tax by certain undertakings and branches - COM (2016) 198 final - Strasbourg, 12.4.2016.

Interinstitutional Agreements between the European Parliament, the Council of the European Union and the European Commission on better law-making of 13 April 2016.

Communication from the Commission to the European Parliament, the Council, the European Economic and Social Committee and the Committee of the Regions "European Standards for the 21st Century" - COM (2016) 358 final - Brussels, 1.6.2016.

European Commission Communication from the Commission - "EU law: Better results through better application" - C/2016/8600 - (2017/C 18/02) - 19.1.2017.

Communication from the Commission to the European Parliament, the Council, the European Economic and Social Committee and the Committee of the Regions - "European Interoperability Framework - Implementation strategy" - COM (2017) 134 final - Brussels, 23.3.2017.

Communication from the Commission to the European Parliament, the Council, the European Economic and Social Committee and the Committee of the Regions - "On the Mid-term Review of the Capital Markets Union Action Plan" - COM (2017) 292 final - Brussels, 8.6.2017.

Proposal for a Council Directive amending Directive 2011/16/EU as regards automatic exchange of obligatory information in the field of taxation with regard to cross - border mechanisms to be communicated - COM (2017) 335 final - Brussels, 21.6.2017.

Communication "Resilience, deterrence and defense: building strong cybersecurity for the EU" - JOIN (2017) 450 - Brussels, 13.9.2017.

Communication from the Commission to the European Parliament and the Council - "A fair and efficient tax system in the European Union for the digital single market" - COM (2017) 547 final - Brussels, 21.9.2017.

Communication from the Commission to the European Parliament, the Council and the European Economic and Social Committee - "On the follow-up to the Action Plan on VAT Towards a single EU VAT area - Time to act” - COM (2017) 566 final - Brussels, 4.10.2017.

Communication from the Commission to the European Parliament, the Council, the European Economic and Social Committee and the Committee of the Regions - "Commission Work Program 2018" - COM (2017) 650 final - Strasbourg, 24.10.2017 and Annex 1.

Opinion of the European Economic and Social Committee on Taxation of the collaborative economy - analysis of possible tax policies faced with the growth of the collaborative economy (exploratory opinion requested by the Estonian presidency) (2018/C 081/09) - 2.3.2018.

Proposal for a Directive of the European Parliament and of the Council amending Directive 2009/65/EC of the European Parliament and of the Council and Directive 2011/61/EU of the European Parliament and of the Council as regards the cross-border distribution of collective investment funds - COM (2018) 92 final - Brussels 12.3.2018.

Communication from the Commission to the European Parliament and the Council - "Time to establish a modern, fair and efficient taxation standard for the digital economy" - COM (2018) 146 final - Brussels, 21.3.2018.

Proposal for a Council Directive laying down rules relating to the corporate taxation of a significant digital presence - COM (2018) 147 final - 2018/0072 (CNS) - Brussels, 21.3.2018.

Commission staff working document summary of the impact assessment accompanying the document - Proposal for a Council Directive laying down rules relating to the corporate taxation of a 
significant digital presence and Proposal for a Council Directive on the common system of a digital services tax on revenues resulting from the provision of certain digital services [COM (2018) 147 final $\}$ - \{COM (2018) 148 final $\}$ - Brussels, 21.3.2018.

Communication from the Commission to the European Parliament, the Council and the European Economic and Social Committee - "A New Deal for Consumers" - COM (2018) 183 final Brussels, 11.4.2018.

Communication from the Commission to the European Parliament, the European Council, the Council, the European Economic and Social Committee and the Committee of the Regions - "Artificial Intelligence for Europe" - COM (2018) 237 final - Brussels, 25.4.2018.

Commission Staff Working Document Executive Summary of the Impact Assessment - Accompanying the document Proposal for a Directive of the European Parliament and of the Council amending Directive (EU) 2017/1132 as regards the use of digital tools and processes in company law and Proposal for a Directive of the European Parliament and of the Council amending Directive (EU) 2017/1132 as regards cross-border conversions, mergers and divisions - SWD (2018) 142 final - 2018/0113 (COD) - Brussels, 25.4.2018.

Communication from the Commission to the European Parliament, the European Council, the Council, the European Economic and Social Committee and the Committee of the Regions - "A new European Agenda for Research and Innovation - Opportunity for Europe to chart its future" COM (2018) 306 final - Brussels, 15.5.2018.

Communication from the Commission to the European Parliament, the European Council, the Council, the European Economic and Social Committee and the Committee of the Regions "Completing a trusted Digital Single Market for all The European Commission's contribution to the Informal EU Leaders' meeting on data protection and the Digital Single Market in Sofia on 16 May 2018" - COM (2018) 320 final e ANNEX - Brussels, 15.5.2018.

Report from the Commission - Monitoring the application of European Union law 2017 Annual Report - COM (2018) 540 final - Brussels, 12.7.2018.

Tax Challenges Arising from Digitalization - Interim Report 2018. Available at http://www.oecd.org/ctp/tax-challenges-arising-from-digitalisation-interim-report9789264293083-en.htm. [Accessed 25 October 2018] 